\title{
PRÁTICAS ESCOLARES E PODER DISCIPLINAR: RELATO DE UMA OBSERVAÇÃO PARTICIPANTE À LUZ DO PENSAMENTO DE MICHEL FOUCAULT
}

\author{
SCHOOL PRACTICES AND DISCIPLINARY POWER: REPORT OF A PARTICIPANT \\ OBSERVATION IN THE LIGHT OF MICHEL FOUCAULT'S THOUGHT \\ https://orcid.org/0000-0003-3656-8653 Sandy Aparecida Barbosa Magalhães A \\ (iD) https://orcid.org/0000-0003-0391-4169 Rafael Baioni do Nascimento ${ }^{\mathrm{B}}$ \\ ${ }^{\text {A }}$ Universidade Estadual de Montes Claros (Unimontes), Montes Claros, MG, Brasil \\ ${ }^{\text {B }}$ Universidade Estadual de Montes Claros (Unimontes), Montes Claros, MG, Brasil \\ Recebido em: 30 abr. 2020 | Aceito em: 8 jun. 2020 \\ Correspondência: Sandy Aparecida Barbosa Magalhães (sandy.magalhaes91@gmail.com)
}

\begin{abstract}
Resumo
Este artigo decorre de um estudo produzido a partir das práticas normativas observadas no cotidiano da escola. Dispõe por objetivo identificar quais e como os processos disciplinares de normalização são postos em movimento nas práticas pedagógicas de professores/as e gestores/as que atuam na educação escolar, tendo por subsídio os estudos do filósofo Michel Foucault. Para tanto, realizamos uma pesquisa de campo de natureza qualitativa, tendo por lócus uma Escola Pública do Município de Montes Claros-MG. Como instrumento de coleta de dados, fizemos uso do método da observação participante. Durante nosso caminho investigativo, foi possível verificarmos algumas das maneiras por meio das quais a escola exerce constante vigilância e intervenção sobre os corpos, mediante vários dispositivos de poder em funcionamento em suas práticas diárias.
\end{abstract}

Palavras-chave: processo disciplinar; normalização; práticas pedagógicas.

\begin{abstract}
This article stems from a study produced from the normative practices observed in school's daily life. It aims to identify which and how the disciplinary standardization processes are set in motion in the pedagogical practices of teachers and managers who work in school education having as a subsidy studies of the philosopher Michel Foucault. Therefore, it was conducted a qualitative field research in a Public School in Montes Claros-MG as its locus. As a data collection instrument, we used a participant observation method. During our investigative path, it was possible to verify some of the ways in which the school exercises constant vigilance and intervention over the bodies, through various power devices operating in its daily practices.
\end{abstract}

Keywords: disciplinary proceeding; standardization; pedagogical praticals. 


\section{Introdução}

Partindo da concepção de que a escola é um dos meios contemporâneos utilizados pelos Estados-nação na fabricação de sujeitos, propomos, com este estudo, investigar quais e como os processos disciplinares de normalização são postos em movimento nas práticas pedagógicas de professores/as e gestores/as que atuam na Educação Escolar.

Para isso, realizamos uma pesquisa de campo em uma escola pública do município de Montes Claros - MG, cujo método investigativo adotado foi a observação participante, por permitir um acesso direto ao cotidiano da escola. O referencial teórico foi embasado pelo pensamento do filósofo Michel Foucault, tendo em vista sua rica contribuição para o estudo da subjetividade e dos dilemas impostos pelo regime disciplinar exercido nos saberes e práticas escolares.

Foucault (2003) expõe que até meados do século XVII, o regime disciplinar já era praticado em algumas instituições, como nos conventos, nos exércitos, entre outros. Mas, a partir da segunda metade desse mesmo século, os seus dispositivos convertem-se em fórmulas gerais de dominação, estendendo-se a diversas outras instituições como presídios, hospitais e escolas. Com isso, toda uma engenharia de normalização e domesticação dos corpos - para melhor governá-los - foi disseminada, uma vez que, para o autor, a disciplina se configura em técnicas de coerções que muitas vezes são sutis, por meio de um exame minucioso do tempo, do espaço e dos corpos dos indivíduos, com intuito de vigiá-los e de controlá-los.

Com a expansão do poder disciplinar, as punições corpóreas violentas são substituídas por formas mais "suaves" de controle, uma vez que, para o sistema econômico capitalista, uma punição que cause danos à força de trabalho não é interessante. Foucault (2003) denomina esse processo de economia do corpo como sendo dispositivos "que não recorram a castigos violentos ou sangrentos, mesmo quando utilizam métodos 'suaves' de trancar ou corrigir, é sempre do corpo que se trata - do corpo e de suas forças, da utilidade e da docilidade delas, de sua repartição e de sua submissão" (FOUCAULT, p.12, 2003).

A escola é justamente uma das principais instituições de exercício desse poder disciplinar, de normatização e de domesticação dos corpos. Por essa razão, esse estudo justificase pela possibilidade de que esses movimentos sejam discutidos com criticidade nas instituições de ensino. 


\section{O Cenário e a metodologia da pesquisa}

Objetivando identificar quais e como os processos disciplinares de normalização são postos em movimento nas práticas pedagógicas de professores/as e gestores/as que atuam na Educação Escolar, optamos por realizar um estudo qualitativo em uma Escola Pública do Município de Montes Claros-MG que atende a alunos/as dos Anos Iniciais do Ensino Fundamental $-1^{\circ}$ ao $5^{\circ}$ ano. Para este fim, apoiamo-nos na concepção de normalização de Foucault (1995), que nos dá ferramentas para analisar de que modos os saberes e as práticas nas instituições escolares contribuem para o achatamento das singularidades em favor de corpos e de subjetividades padronizadas. Esse processo utiliza-se de procedimentos de inclusão e exclusão, pautados no binômio normal e anormal, como por exemplo, “o louco e o são, o doente e o sadio, os criminosos e os bons meninos" (FOUCAULT, 1995, p. 231).

A escola observada situa-se em uma área periférica, seu corpo discente é composto majoritariamente por uma população não branca e de baixa renda. De acordo com os últimos resultados divulgados do Índice de Desenvolvimento da Educação Básica - Ideb, a escola pesquisada obteve a nota 5,8. Segundo o Ministério da Educação, o Ideb é

\footnotetext{
formulado para medir a qualidade do aprendizado nacional e estabelecer metas para a melhoria do ensino. (...)Para tanto, o Ideb é calculado a partir de dois componentes: a taxa de rendimento escolar (aprovação) e as médias de desempenho nos exames aplicados pelo Inep. Os índices de aprovação são obtidos a partir do Censo Escolar, realizado anualmente (BRASIL, 2007).
}

A escola não atingiu as metas, os índices propostos e, assim, sua situação se encontra em alerta, uma vez que foi o $6^{\circ}$ pior resultado dentre as escolas públicas (municipal e estadual) do município. Contudo, o Censo Escolar anual é realizado a partir de exames padronizados, como a Prova Brasil e o Sistema de Avaliação da Educação Básica - Saeb, sendo estes exames tão somente quantitativos, que não consideram todos os elementos que integram as escolas em suas especificidades e funcionalidades. Estas circunstâncias, tais como, a valorização profissional, o piso salarial compatível com a função, a quantidade de discentes por sala, uma infraestrutura bem equipada, a oferta de cursos de formação, aperfeiçoamento para os docentes, e principalmente, o aumento do valor de financiamento da educação são alguns dos pontos que não são considerados pelo Ideb, acarretando vastos obstáculos que influenciam diretamente no rendimento escolar desses/as estudantes. 
Para coleta de dados, fizemos uso do método observação participante. Essa escolha deuse em função de que a percebemos como a que melhor atenderia aos nossos propósitos, uma vez que pretendíamos adentrar o espaço de pesquisa e assumirmos o papel de integrantes do grupo. Além disso, acreditamos que assim estaríamos compartilhando os papeis e rotinas dos grupos observados, sem que nossa presença provocasse repressões ou adulterações nos atos corriqueiros, praticados e vivenciados pelos sujeitos da pesquisa. Para a análise dos dados, apoiamo-nos nas teorias de Michel Foucault em relação ao regime disciplinar, que nos deu suporte para compreendermos as situações presenciadas no cotidiano escolar.

Iniciamos nosso estudo concomitantemente ao calendário escolar para vivenciarmos as práticas dos professores/es e gestores/as a partir do acolhimento inicial aos alunos. Por se tratar de um estudo que busca observar práticas normalizadoras, acreditamos que estas estão mais acentuadas nos primeiros contatos do corpo administrativo e docente com os estudantes, bem como, para a nossa inserção natural ao grupo.

Observamos uma turma do $1^{\circ}$ e uma do $5^{\circ}$ ano do Ensino Fundamental, compostas por aproximadamente 25 estudantes cada uma. Ambas são regidas por professoras; a do $1^{\circ}$ ano exerce o cargo há 20 anos e a do $5^{\mathrm{a}}$ há 25 anos. As duas possuem Magistério e graduação em Pedagogia. A faixa etária dos/as estudantes do $1^{\circ}$ ano era de seis a sete anos, e do $5^{\circ}$, de dez a onze anos. Também acompanhamos os momentos extraclasses, como o recreio e apresentações artísticas. Nesses momentos, havia alunos de todos os anos contemplados pela Escola.

A escolha de observarmos essas turmas deu-se em função de entendermos - devido as nossas vivências enquanto educadores - que a turma do $1^{\circ}$ ano está mais suscetível a práticas normativas, devido ao fato de ser este o primeiro contato, por grande parte dos/as alunos/as, com a educação escolar sistematizada. Em consequência, há grande reiteração das normativas disciplinares. A turma do $5^{\circ}$ ano, devido a maioria dos/as estudantes já estarem inseridos na escola desde os anos anteriores e familiarizados com as normativas ali postas, poderíamos visualizar com maior clareza a efetivação das normas disciplinares no processo de subjetivação desses corpos.

As observações totalizaram em média $100 \mathrm{~h}$ em cada turma e $12 \mathrm{~h}$ nos momentos extraclasse, entre os meses de fevereiro e março de 2020. Durante esse período, acompanhamos e demos suporte aos docentes e discentes na realização das atividades. Observamos, também, as aulas de Educação Física, durante aplicação de conteúdos referentes a jogos, brincadeiras e esportes, sendo essa uma fonte riquíssima de informações para o nosso estudo. 


\section{O cotidiano escolar e suas práticas disciplinares de normalização}

Ao adentrarmos o espaço escolar pesquisado, foi possível observarmos as práticas e discursos disciplinares normativos que são reproduzidos pelos profissionais que ali atuam, bem como a estrutura física da escola, visto que a compreendemos como o primeiro instrumento de disciplina usado para delimitar os corpos dos estudantes.

A escola que observamos segue os padrões das escolas tradicionais do sistema educacional público nacional. Há um pátio central, as salas de aula e os recintos administrativos, como a Secretaria e as salas da Direção, são construídos em seu entorno, sendo estas postas em pontos estratégicos, onde é possível visualizar todo o espaço escolar.

Esse sistema arquitetônico não é feito aleatoriamente; ele é pensado e calculado com o intuito de vigiar aqueles que o adentram. Foucault (2003) faz uso do estudo de Jeremy Bentham sobre o Panóptico para expor essa tática de vigilância. O Panóptico é uma disposição arquitetônica aparelhada para cárceres e prisões, formada por uma composição de células em volta de um ponto central. No centro estaria uma torre de vigia, na qual uma única pessoa poderia vigiar todos os reclusos em suas células. Contudo, os reclusos não conseguiam visualizar se estavam ou não sendo vigiados. A estrutura da torre era construída de forma que quem estivesse do lado externo não conseguia enxergar se havia alguém em seu interior. Logo, o prisioneiro precisaria controlar sua conduta para evitar punições, pois poderia estar sendo fiscalizado a qualquer momento, sem que o soubesse.

Todo esse movimento foi notado no campo escolar observado. Além da estrutura física condizente ao Panóptico de Bentham, o efeito que ele causa aos alunos também atua à disposição das normativas escolares. Essa estrutura arquitetônica é um dispositivo comparte ao da disciplina, em razão de automatizar e desindividualizar o poder, ou seja, seus princípios não estão em um indivíduo específico, qualquer um pode fazer funcionar seus mecanismos de poder; a própria arquitetura viabiliza essa atuação.

Nesse sentido, foi notório o temor dos discentes diante uma possível vigilância dentro e fora da sala de aula. Mesmo na ausência dos/as professores/as ou gestores/as, os/as estudantes apresentavam receio de praticar algum ato considerado impróprio pela escola, pois temiam que pudessem estar sendo vistos ou que o/a vigilante chegaria a qualquer momento. Como foi possível observarmos nos momentos em que a professora se ausentava da sala de aula, alguns alunos/as aproveitavam esse momento para conversar com outros colegas ou para levantar das carteiras. Porém, o/a aluno/a que se sentava próximo a porta, sempre vigiava se a docente estava 
chegando, alertando aos demais para voltar a seus postos, sem serem vistos. A nossa presença em sala de aula também ocasionava certo receio, os/as estudantes temiam que contássemos os seus atos "impróprios" para a regente da turma.

Durante as atividades realizadas na sala, os/as estudantes eram dispostos sentados em filas, enquanto a docente permanecia de pé. A figura central da educadora, enquanto detentora da autoridade máxima, ocasionava a conduta idealizada proposta aos estudantes. Nos momentos extraclasses, quaisquer que fossem os profissionais presentes, acarretavam a mesma postura por parte dos alunos, que aparentavam certo temor diante desses indivíduos, como no momento do recreio. Durante esse momento, se algum profissional estivesse presente, os/as estudantes se portavam de forma mais contida - como é o esperado pela escola. Caso contrário, se não notassem a presença do profissional, agiam de maneira desinibida, e até mesmo descumpriam regras impostas pela escola, como não correr, não gritar, entre outras.

Foucault (2003) atribui esse contexto à Vigilância Hierárquica, isto é, os comportamentos dos indivíduos são constantemente vigiados por outros indivíduos hierarquicamente superiores, como o professor que vigia o aluno, o carcereiro que vigia o prisioneiro, etc. Ao observarmos o dia a dia escolar, percebemos o quanto essa vigilância se faz presente em todos os momentos e espaços. Há sempre um corpo detentor da autoridade que "guarda" os corpos "vigiados". Diariamente, os/as estudantes do turno matutino chegam à escola às $07 \mathrm{~h}$. Ao adentrarem o ambiente, se deparam com uma servidora orientando-os a se posicionarem na fila correspondente a sua turma. Em cada fila, há o/a docente responsável. Cada turma possui duas filas: uma de meninas e uma de meninos ${ }^{\mathrm{i}}$. Pontualmente, às $07 \mathrm{~h} 15$ min, realiza-se uma oração cristã ${ }^{\text {ii }}$ com a participação dos alunos. Durante esse momento, os/as docentes ficam atentos aos/as estudantes, pois todos devem repetir a oração. Caso contrário, são repreendidos/as pelo/a profissional.

Encerrado esse momento, todos se encaminham para as salas de aula, ainda em fila, com os braços para trás - os alunos não podem se tocar, desde a ordenação até o desfazer da fila. Nesse momento, a docente permanece na porta, observando todos os alunos entrarem. Toda essa sistemática está tão arraigada nos espaços escolares que os/as atuantes a veem como algo natural, como se esse sistema sempre estivesse em vigor dentro da educação. Ao perguntarmos aos/as professores/as e gestores/as o porquê de o acolhimento aos estudantes ser dessa forma, foram unânimes as respostas de que "sempre foi assim", que era necessário para "manter os alunos em ordem". 
A vigilância se torna ainda mais exposta dentro da sala de aula. Nas duas turmas que observamos, as práticas e discursos disciplinares, exercidos pelas professoras, são recorrentes. Por realizarmos as observações no início do ano letivo, foi possível acompanharmos práticas comuns exercidas pelas escolas, como as "regras de bom convívio", que são impostas aos estudantes nos primeiros dias de aula. Dentre os alunos do $1^{\circ}$ ano, para a maioria, esse era e primeiro contato com a escola. Ao conversarmos informalmente com a docente responsável por essa turma, a questionamos o motivo pelo qual ela opta por lecionar para o mesmo ano escolar durante anos. Ela nos informou que fazia essa escolha justamente por que o $1^{\circ}$ ano é o primeiro contato dos/as discentes com a escola. Assim - em suas palavras - ela considera "muito mais fácil domá-los a seu modo, pois não há influência de outras professoras sobre eles".

Logo no primeiro dia, a docente ditou aos estudantes as regras que ela julgava ser fundamentais para o "bom" desenvolvimento e convívio de todos. Elas são:

1.Respeitar os colegas e todos os funcionários da escola; 2.Trazer o material completo; 3.Usar sempre o uniforme; 4.Permanecer na sala de aula; 5.Evitar brigas; 6.Cuidar do jardim e zelar pelas demais plantas da escola; 7.Ser frequente; 8.Jogar lixo na lixeira; 9.Evitar subir nos bancos; 10.Trazer a garrafa com água; 11.Ir ao banheiro somente no intervalo do recreio; 12.Não comer na sala de aula; 13 .Não conversar com o colega dentro da sala de aula; 14.Não usar o material do colega; 15.Levantar a mão quando quiser falar; 16.Ser pontual; 17.Sentar no lugar marcado; 18. Fazer as atividades; 19. Fazer as tarefas de casa.

É sabido que, para o funcionamento de uma instituição, as regras são necessárias para se atingir seus fins educativos. No entanto, dentre as regras propostas pelas docentes, podemos perceber que nem todas atendem a uma prática pedagógica proveitosa para a manutenção desse sistema, como, por exemplo, ir ao banheiro somente no intervalo do recreio, não comer na sala de aula, não conversar com o colega dentro da sala de aula, não usar o material do colega, sentar no lugar marcado. A nosso ver, são regras arbitrárias e coercitivas, não há nenhum efeito assegurado que as justifiquem ou causem interferências no funcionamento idealizado pela escola. Outro ponto que nos inquietou foi durante a exposição das regras, nenhuma das professoras dialogou com os/as alunos/as sobre a finalidade e o motivo de serem estas as regras para o bom convívio em turma. As regras foram simplesmente postas para os/as estudantes, sem nenhum espaço para questionamentos ou opiniões; eles/as não dispuseram de voz diante as determinações, apenas as acataram.

Aqueles que não seguissem as regras sofreriam penalidades. A professora anexou na parede um quadro contendo o nome dos/as discentes. A cada "mau" comportamento eles/as receberiam uma bolinha vermelha, aqueles que se destacassem por comportarem conforme o 
esperado, iria receber uma bolinha azul. A cada bolinha vermelha era um dia sem recreio. $\mathrm{Na}$ sexta-feira, seria contabilizada a quantia de bolinhas vermelhas e azuis. Os que somassem mais bolinhas vermelhas - os "maus" comportados - teriam que fazer um trabalho extra e apresentálo na segunda-feira. Os que a bolinha azul predominasse, não levariam a tarefa para fazer em casa por dois dias. Aqui podemos perceber o quanto a escola atribui maior valor a disciplina do que ao aprendizado. A tarefa, que deveria servir para aprender, é usada como punição para o mau comportamento. Ela não tem valor em si, ela está em função do objetivo de disciplinar. Tal qual é exposto por Foucault (2003) em sua obra Vigiar e Punir, a datar de meados do século XIX, a punição abstém-se dos suplícios e passar a atuar por meio de coerções ante o corpo, sendo que "o corpo é colocado num sistema de coação e de privação, de obrigações e de interdições [...] o castigo passou de uma arte das sensações insuportáveis a uma economia dos direitos suspensos". (FOUCAULT, 2003, p. 15).

Essa era uma tática indicada pela gestão escolar, pois a professora do $5^{\circ}$ ano também utilizava a mesma para avaliar o comportamento dos alunos. Contudo, por já se sentirem pertencentes ao espaço escolar, os alunos dessa turma mostraram mais resistência às regras impostas. Salientamos o discurso de uma estudante que insistia que as regras deveriam ser feitas juntamente com os alunos "já que são eles que devem cumpri-las". Como esperado, não foi ouvida, e sim silenciada. A docente a interrompeu com uma fala extremamente autoritária, informando-a que, enquanto ela regesse a turma, era ela quem estabelecia as regras e cabia aos alunos obedecê-la. Caso contrário, informaria a direção o ocorrido. Mais uma vez, podemos ver de forma explícita a disparidade da vigilância hierárquica no campo escolar e sua combinação com as técnicas da sanção normalizadora.

O poder disciplinar atua por meio da sanção normalizadora ditando as rotulações e demarcações de desvios, incorporando-se à norma ao provocar e tratar o que a ela se distancia ou diferencia. Essas sanções podem ser exteriorizadas tanto como prêmio como punição. Elas operam em um sentido corretivo de modo a regular os sujeitos a níveis mais próximos da norma, intentando, assim, concebê-los como normais, sendo esse um dos princípios da disciplina. Podemos vê-la fielmente na metodologia exercida pelas docentes supracitadas. Ao definir o que se enquadra em bom ou mau comportamento, a escola define a norma a ser seguida, e aqueles que as seguem sofrem sanções gratificantes, não realizando o dever de casa, visto que este exercício é praticado como uma ação corretiva. Em contrapartida, os que subvertem essas normas sofrem sanções punitivas, como não serem autorizados a participar do recreio e receberem um dever extra para ser feito casa. 
A sanção normalizadora fixa regras a todos os que dela se desviam. Nessa perspectiva, as "regras de bom convívio", definidas pelas docentes, configuram-se uma real amostra dessas táticas, pois elas estabelecem

toda uma micropenalidade do tempo (atrasos, ausências, interrupções das tarefas), da atividade (desatenção, negligência, falta de zelo), dos discursos (tagarelice, insolência), do corpo (atitudes incorretas, gestos não conformes, sujeira), da sexualidade (imodéstia, indecência) (FOUCAULT, 1987, p. 203).

Para além delas, todo tempo-espaço escolar é marcado por normativas disciplinares, que, em sua maioria, não atuam em proveito de uma educação democrática e emancipadora. Esse movimento se mostra ainda mais ostensivo nas aulas de Educação Física. Durante esses momentos, os dispositivos disciplinares e regulatórios de normalização são demasiadamente postos sobre os corpos. Nesse sentido, Carmem Lúcia Soares diz que "herdeira de uma tradição científica e política que privilegia a ordem e a hierarquia desde sua denominação inicial de Ginástica, a hoje chamada Educação Física foi e é compreendida como um importante modelo de educação corporal que integra o discurso do poder" (SOARES, 2011, p. 115).

Assim, durante nossas observações, foi possível acompanharmos toda essa dinâmica. As aulas são ministradas por um professor atuante há mais de 30 anos na Educação Básica. Acreditamos que por possuir uma formação passada, moldada nos preceitos da época, isso contribui para o docente ainda trazer consigo metodologias tradicionais, que vão de encontro com as discussões atuais relacionadas à educação do corpo e à diversidade.

Em todas as aulas, os/as estudantes são separados binariamente, isto é, as meninas realizando uma atividade e os meninos outra. Em nenhum momento eles atuam em conjunto. Enquanto aos meninos são destinadas atividades que envolvem mais ação, como jogos com bola, às meninas são designadas tarefas que não exigem força e movimentos bruscos, como os jogos de tabuleiro. E, mesmo durante a realização das atividades já preestabelecidas, os alunos são monitorados em todos seus movimentos.

Ao questionarmos o educador de o porquê dessa divisão, ele foi efêmero ao dizer que "não havia motivos para juntá-los, pois isso só traria confusão, uma vez que as meninas são mais frágeis, e, desde cedo, cada um já deve saber o seu papel. Bola é para menino. Às meninas cabem outros tipos de jogos". Reafirmamos que não intentamos nesse trabalho discutir as normativas de gênero, uma vez essa temática faz jus a um estudo dedicado somente a ela e, assim, será feito posteriormente. Contudo, não é possível deixarmos de lado esses dados, mesmo que o abordemos de forma breve, pois em todas as práticas e discursos disciplinares cometidos pelos/as educadores/as e gestores/as, a normativa de gênero se fez presente. 
Verificamos que essa prática não é perpetuada apenas por este professor. Majoritariamente, os profissionais da escola participante atuam para a disparidade de gênero, desde a divisão das filas entre meninos e meninas, a não aceitação de comportamentos que não se enquadram nessa lógica binária do feminino e masculino. Foi recorrente ouvirmos falas de que certas brincadeiras eram femininas ou masculinas, que determinado aluno era "estranho", pois só brincava com meninas, que os meninos são agitados devido sua natureza, que as meninas são mais frágeis... entre tantas outras que contribuem para a hierarquia de gênero, imprimindo, desde as mais tenras idades, a regularização de uma sociedade patriarcal. Nesse sentido, Louro diz que a escola "reproduz padrões sociais, perpetua concepções, institui verdades, opera com determinadas representações, fabricando sujeitos generificados e sexualizados de acordo com os discursos normativos de gênero e sexualidade" (LOURO, 1997, p. 156). A heteronormatividade atua na escola por meio de inúmeras estratégias que tendem a rotular, inferiorizar, vigiar, controlar e disciplinar aqueles que não seguem determinados padrões, como, por exemplo, meninos que brincam com brinquedos considerados femininos, meninas que preferem a cor azul à cor rosa, entre outras atitudes que coloquem em questão a sexualidade desses sujeitos, dado que

desde seus inícios, a instituição escolar exerceu uma ação distintiva. Ela se incumbiu de separar os sujeitos [...]. A escola delimita espaços. Servindo-se de símbolos e códigos, ela afirma o que cada um pode (ou não pode) fazer, ela separa e institui. Informa o "lugar" dos pequenos e dos grandes, dos meninos e das meninas. (LOURO, 1997, p. 61 e 62).

Esta concepção dos gêneros, construída dentro de uma lógica dicotômica, resulta o feminino e o masculino em uma forma fixa, preestabelecida, ignorando ou rejeitando todos os indivíduos que socialmente não se enquadram nesses padrões. Em seus estudos, Foucault (1993) endossa que a sexualidade não é natural e inerente aos corpos, mas sim produzida, pois o poder disciplinar regula e normaliza tudo que concerne ao corpo; ela abrange um processo contínuo de práticas e reflexão, sendo uma construção histórica, social e cultural. Assim, no que se concerne à educação escolar e aos sujeitos, Soares diz que

a partir dos desenhos que traçam no espaço com sua materialidade, os corpos e sua gestualidade podem permitir a compreensão de toda uma dinâmica de elaboração dos códigos a que devem responder, das técnicas, pedagogias e instrumentos desenvolvidos para submetê-los a normas (SOARES, 2011, p. 113).

Nesse contexto, a sanção é normalizadora, posto que propicia o funcionamento da disciplina por meio do assentamento da norma à medida que consente avaliar e julgar, normalizando mediante comparação, diferenciação, hierarquização, homogeneização e 
exclusão. Assim, por meio do exame, suas técnicas, juntamente com as da vigilância hierárquica, são postas em movimento.

Nos estudos foucaultianos, o exame se manifesta como uma tática de poder e saber, sendo que a concepção de saber é distinta da ideologia e a de poder é distinta da repressão. Tanto ideologia quanto repressão atestam negatividade, enquanto, para Foucault, o poder-saber também manifesta atuação positiva. A produtividade presente nos dispositivos de poder afasta a ideia de repressão, uma vez que esta cumpre-se apenas por meio de normas proibitivas e punitivas, indo de encontro às várias táticas, técnicas, procedimentos e instrumentos de saberpoder que se colocam em exercício em mecanismos positivos, como os agentes de saber, os propagadores de discursos, os produtores de prazer, entre outros.

Da mesma maneira, Foucault (2009) diferencia saber de ideologia, em razão desta estar sempre em oposição à verdade, sendo que, para ele, a verdade não se define pela sua compreensão semântica, nem pelas suas vastas possibilidades de significação; trata-se de um conjunto de práticas que instituem um dispositivo em sua concretude e não é fixada como uma verdade em si. A verdade emerge por um "conjunto de procedimentos regulados para a produção, a lei, a repartição, a circulação e o funcionamento dos enunciados (...) esse regime não é simplesmente ideológico ou superestrutural; foi uma condição de formação e desenvolvimento do capitalismo" (FOUCAULT, 1988, p.14).

Nesse sentido, não existe verdade sem poder e não há poder sem verdade; estão intrínsecos. Não há uma dualidade no poder entre o certo e o errado; o dominador e o dominante, entre outras. O poder é múltiplo, não tem como ser centralizado, pois está posto em todas as correlações de força que o constituem. Ele está em toda parte, não é pertencente somente a um ser ou a uma instituição. Desse modo, o poder e o saber estabelecem estreita relação, se constituem em recíproca dependência.

Logo, a escola usa desse saber para exercer poder de diversas formas e o exame é uma delas. A instituição escolar se porta como um aparelho de exame contínuo que acompanha as técnicas de ensino em todas as suas dimensões. $\mathrm{O}$ exame propicia que o educador, ao mesmo tempo em que transmite seu saber, produza um campo de conhecimento junto aos seus alunos, isto é, "o exame é na escola uma verdadeira e constante troca de saberes: garante a passagem dos conhecimentos do mestre ao aluno, mas retira do aluno um saber destinado e reservado ao mestre. A escola torna-se o local de elaboração da pedagogia" (FOUCAULT, 2003, p. 155).

Foucault (2003) destaca três características do exame: 1) O exame inverte a economia da visibilidade no exercício do poder: tradicionalmente o poder é aquilo que é visto e exercido, 
quanto mais se mostra mais força detém. Contudo, o poder disciplinar rompe com essa concepção. Ele se exerce ao tornar-se invisível, exige aos que sujeita "um princípio de visibilidade obrigatória" (FOUCAULT, 2003, p. 211). Vemos esse exemplo na figura da direção e/ou supervisão na escola observada. Elas não precisam estar presentes, mas as concepções de autoridade e de detenção de poder que são determinadamente induzidas a esses cargos, fazem com que os/as estudantes as temam mesmo em sua ausência, independentemente de quem exerça o cargo.

2) $O$ exame faz também a individualidade entrar num campo documentário: “(...) seu resultado é um arquivo inteiro com detalhes e minúcias que se constitui ao nível dos corpos e dos dias. O exame que coloca os indivíduos num campo de vigilância situa-os igualmente uma rede de anotações escritas" (FOUCAULT, 2003, p. 157). Todos os alunos são devidamente registrados e definidos nos "diários de classe". Como iniciamos nossa observação no início do ano letivo, as professoras ainda não possuíam materiais a serem registrados, pois a cada estudante é destinado uma página em que são registradas observações referentes ao seu desenvolvimento. $\mathrm{Na}$ turma do $1^{\circ}$ ano, a professora aplicou um teste diagnóstico, que serve para "medir" o nível de desenvolvimento do/a discente. Quanto mais acerto obtiver no teste, maior seu nível de inteligência e seu laudo, registrado no diário de classe. A partir daí, todo seu ano letivo e desenvolvimento baseiam-se nas anotações que são postas pela docente. Já na turma do $5^{\circ}$ ano, pelo fato de os/as estudantes estudarem na mesma escola desde os anos anteriores, a professora do ano atual recorre ao diário de classe do ano precedente para analisar e "conhecer" seus alunos. As impressões dispostas são as que definem quem é aquele sujeito. Desde as notas, os bons e maus comportamentos, as aptidões e dificuldades, tudo relacionado à vida escolar é registrado no diário. Esse exercício se faz ainda mais explícito diante os estudantes que possuem a Classificação Internacional de Doenças e Problemas Relacionados à Saúde - CID-10. Estes são caracterizados e definidos exclusivamente pelas suas especialidades.

3) O exame, cercado de todas as suas técnicas documentárias, faz de cada indivíduo um "caso": ou seja, "é o indivíduo tal como pode ser descrito, mensurado, medido, comparado a outros e isso em sua própria individualidade; e é também o indivíduo que tem que ser treinado ou retreinado, tem que ser classificado, normalizado, excluído, etc" (FOUCAULT, 1987, p. 216). Voltemos ao exemplo do diário de classe, em que, a partir do momento que os/as estudantes são registrados, ele passa a ser a identidade desses corpos, cada sujeito passa a ser um "caso" a ser analisado e melhorado quando preciso. 
A professora do $5^{\circ}$ ano por possuir os "laudos" do ano anterior, os utilizou como base para classificar seus estudantes e, assim, para mapear o local em que cada um ficaria na sala, visando ao "melhor desenvolvimento" dos "retardatários" que constam no diário de classe. Os alunos "retardatários" foram dispostos em duas fileiras à direita da sala, enquanto os demais ocuparam as outras filas. Ao perguntarmos de o porquê separá-los, a professora proferiu que os separando poderia destinar a eles maior atenção, objetivando a padronização do desenvolvimento intelectual dos/as discentes. Em nenhum momento foram consideradas as suas individualidades, pois há um nível normalizado de aprendizagem que os/as estudantes devem seguir. Aqueles que não correspondem ao esperado são suprimidos em suas subjetividades e devem alcançar os "adiantados", pois só assim serão vistos como normais, atenderão aos propósitos utilitários. Entretanto, durante as nossas observações em sala de aula, não percebemos nenhuma assistência distinta a estes alunos; contrariamente, eles eram negligenciados pela professora regente. A atenção era dada aos demais alunos, enquanto os dispostos nas duas fileiras à direita eram deixados ao nosso cuidado. Cabia a nós auxiliá-los durante a realização das atividades, observando se estavam se comportando como o esperado pela docente.

Investigando essas técnicas do dispositivo disciplinar, Foucault diz que "o exame está no centro dos processos que constituem o indivíduo como efeito e objeto de poder, como efeito e objeto de saber" (FOUCAULT, 1987, p. 216). Logo, seu exercício atua efetivamente no processo de objetivação e de sujeição dos corpos, na "fabricação da individualidade celular, orgânica, genética e combinatória" (FOUCAULT, 1987, p. 216), na qual a diferença individual é conveniente para a sua funcionalidade normativa.

Desse modo, "o corpo também está diretamente mergulhado num campo político; as relações de poder têm alcance imediato sobre ele; elas o investem, o marcam, o dirigem, o supliciam, sujeitam-no a trabalhos, obrigam-no a cerimônias, exigem-lhe sinais" (FOUCAULT, 2003, p.23). Estes são constantemente vigiados e treinados para que sua força de produção esteja em incessante atividade, já que sua utilidade só é possível a partir do momento em que esse corpo, além de produtivo, seja submisso, pois

o momento histórico das disciplinas é o momento em que nasce uma arte do corpo humano, que visa não unicamente o aumento de suas habilidades, nem tampouco aprofundar sua sujeição, mas a formação de uma relação que no mesmo mecanismo o torna tanto mais obediente quanto é mais útil, e inversamente. Forma-se então uma política das coerções que são um trabalho sobre o corpo, uma manipulação calculada de seus elementos, de seus gestos, de seus comportamentos (FOUCAULT, 2003, p.164). 
Portanto, a norma opera sobre o corpo, porquanto este é imbricado ao campo político. Sendo assim, as relações de poder - em uma troca recíproca, já que o corpo é simultaneamente sujeito e objeto de relações de poder; espaço de confronto entre o saber-poder que deliberam pela sua sujeição ou liberdade - investem sobre esse corpo a sua dominação, tencionando sua utilização econômica. Contudo, para que sua composição enquanto força de trabalho efetue-se, é necessário que esteja tolhido em um sistema de sujeição, dado que sua utilidade só é possível ao converter-se em um corpo submisso. Para a efetivação dessa sujeição, os instrumentos da violência ou da ideologia por si só não produzem o efeito esperado ou, por vezes, não aparecem sós. Estes podem ser dispostos de forma direta ou não, em sua maioria, atuam sutilmente e com total ciência dos seus movimentos. Sendo esse processo de saber e de controle uma tecnologia política do corpo, "essa tecnologia é difusa, clara, raramente formulada em discursos contínuos e sistemáticos; compõe-se muitas vezes de peças ou de pedaços; utiliza um material e processos sem relação entre si”" (FOUCAULT, 2003, p. 29).

Desse modo, não é possível localizar esse regime de poder apenas em uma instituição, pois a tecnologia do corpo está a cargo para que dela façam uso. Trata-se de uma microfísica do poder "posta em jogo pelos aparelhos e instituições, mas cujo campo de validade se coloca de algum modo entre esses grandes funcionamentos e os próprios corpos com sua materialidade e suas forças" (FOUCAULT, 2003, p. 30). Assim, ela é um regime que está à disposição para que a exerçam.

A partir do momento que adentram o espaço escolar pesquisado, os/as discentes são decompostos em espaços prefixados. A escola é divida em salas de aula e cada sala corresponde a um ano escolar. Os anos escolares são divididos por idade. Dentro de cada ano, os/as estudantes são separados por nível de aprendizagem, porém cada um se senta só, um atrás do outro. O/a estudante não pode "invadir" outro espaço, exceto o que a ele foi destinado. Durante o recreio, eles/elas devem permanecer apenas no pátio central (assim é mais fácil de vê-los/las e controlá-los/las). Durante o horário de lanche, devem permanecer no refeitório em silêncio (esse momento é para alimentação, não para recreação). Se solicitarem ir ao banheiro, são acompanhados por uma servidora dos serviços gerais (se forem sós, podem se dispersar e ocasionar bagunça). Em qualquer atividade extraclasse, todos devem sair da sala de aula em fila, sendo fila de menina e fila de menino. Durante a saída, as turmas são liberadas aos poucos. $\mathrm{Na}$ sala em que fizemos a observação participante, os/as estudantes são liberados/as para irem embora conforme o comportamento durante o dia. Os de "bom" comportamento saem primeiro. 
Tanto as técnicas citadas quanto outras praticadas pela escola são utilizadas em favor do dispositivo disciplinar de normalização, com intuito de "conhecer, dominar e utilizar" esses corpos, uma vez que as táticas disciplinares organizam os espaços "arquiteturais, funcionais e hierárquicos", intentando manter estes corpos em constante vigília, para que assim o possam classificar e adestrar, atendendo aos anseios utilitários, produzindo uma economia do tempo e dos gestos.

Consequentemente, dentro do espaço escolar, todo tempo é inestimável e não há tempo a perder. Para que isso não ocorra, há um controle contínuo por meio dos "vigilantes", que trabalham para inibir quaisquer manifestações que coloquem em jogo a ordem e os efeitos que procedem da utilidade integral do tempo. Contudo, essa tática só se efetiva se esse corpo atender com exatidão e aplicação aos exercícios do tempo disciplinar, ou seja, "o ato é decomposto em seus elementos; (...) é prescrita sua ordem de sucessão. O tempo penetra o corpo, e com ele todos os controles minuciosos do poder" (FOUCAULT, 2003, p.178).

Às $07 \mathrm{~h}$, os/as estudantes chegam à escola, entram em fila; às $07 \mathrm{~h} 15$ min é feita a oração; às $07 \mathrm{~h} 25$ min eles/as são encaminhados/as para a sala; às 07h 30 min abrem o caderno de tarefa para as professoras vistoriarem; após, são feitas as correções e aquele que errou deve refazer a lição, não sendo aceitos erros registrados no caderno. Assim feito, dá-se início as atividades programadas que, em sua maioria, são retiradas do livro didático ${ }^{\mathrm{iii}}$. É exposta uma pequena explicação sobre o conteúdo, em seguida o quadro negro é preenchido por exercícios de fixação.

As professoras vistoriam se todos estão executando corretamente as lições. Se não o for, devem ser refeitas. A letra não pode ser muito grande, mas também não pode ser pequena, tem que ser bonita, mas tem que ser escrita com agilidade, pois a lousa será apagada para dar lugar a outro exercício. Se alguns conseguem terminar em tempo hábil, então, de acordo com a visão das docentes, todos devem conseguir.

Às 09h $20 \mathrm{~min}$, os/as alunos/as são encaminhados para o refeitório, todos em suas respectivas filas (fila de menino, fila de menina). Às 09h 30 min é o horário de recreio. Porém, os/as estudantes que participam desse momento são aqueles que realizaram todos os exercícios passados no horário anterior. Aqueles que não os fizeram, voltam para a sala para concluí-los. Assim, são privados dos únicos 20 minutos de recreação que a escola concede. Contudo, aos que concede, o faz com ressalvas: "não pode correr", "não sair das mediações do pátio central”, "não fazer muito barulho, pois pode atrapalhar o serviço do secretariado", "os alunos especiais não devem estar em tumulto" (mesmo quando suas especificidades não os limitam em interagir 
e participar de atividades coletivas), entre outras. Às 09h 50 min, retornam em fila para a sala de aula. De imediato, abrem o caderno, porque há mais exercícios na lousa.

Em dias esporádicos, há atividades extraclasses como apresentações teatrais ou comemorações específicas. Quando não há essas atividades, os/as discentes permanecem em sala realizando os exercícios até às $11 \mathrm{~h} 15 \mathrm{~min}$, quando toca o sinal para o encerramento das aulas.

Todos os passos dos estudantes são minunciosamente acompanhados para que produzam satisfatoriamente, porque quanto mais produção, mais utilidade este corpo apresentará. Nessa perspectiva, um arquétipo do normal é estabelecido com a função de coibição e na escola ele se instaura mediante uma educação padronizada. Assim, é desta maneira a biopolítica e o biopoder se consolidam, com corpos que são distintos sob um parâmetro de valor e utilidade, sendo pensados em decorrência da gradativa importância da norma. Em seus estudos, Foucault diz que

a organização de um espaço serial foi uma das grandes modificações técnicas do ensino elementar. Permitiu ultrapassar o sistema tradicional (um aluno que trabalha alguns minutos com o professor, enquanto fica ocioso e sem vigilância o grupo confuso dos que estão esperando). Determinando lugares individuais tornou possível o controle de cada um e o trabalho simultâneo de todos. Organizou uma nova economia do tempo de aprendizagem. Fez funcionar o espaço escolar como uma máquina de ensinar, mas também de vigiar, de hierarquizar, de recompensar (FOUCAULT, 2003, p.173).

Desse modo, vimos na prática como ainda hoje se efetivam as análises de Foucault sobre o poder disciplinar e a escola. Foi possível observar que a instituição escolar se faz um dos sustentos desse sistema, visto que ela atua na produção de uma sociedade normalizadora, por meio das suas estratégias históricas de poder que submetem ao corpo social a classificação e o controle disciplinado das normalidades.

\section{Considerações Finais}

Diante do exposto, podemos constatar que por meio das práticas e discursos exercidos pelos professores/as e gestores/as que atuam na instituição escolar pesquisada, esta trabalha regularmente para a manutenção do sistema de dominação e sujeição dos corpos. O que se busca é a sua utilidade, visto que durante nossa observação, percebemos que em todos os seus atos a escola atua na efetivação do regime disciplinar, fazendo uso de estratégias que são facilmente visualizadas em seu campo. Desde o acolhimento ao encerramento das aulas, os/as estudantes 
são submetidos a técnicas de adestramento e à padronização que visam docilizar e sujeitá-los para uma satisfatória utilidade.

Durante nosso caminho investigativo, foi possível confirmarmos as formulações de Foucault em relação às normativas disciplinares, pois o meio escolar investe sobre esses corpos constante vigilância e intervenção, por meio das suas técnicas de contenção. São diversos os mecanismos de poder-saber que são investidos sobre os/as estudantes, com intuito de retrair as suas utilidades para a manutenção e a configuração da sociedade atual.

Seja dentro ou fora da sala de aula, os/as discentes são constantemente expostos às normativas escolares. A escola detém, por meio da vigilância e das sanções, o controle disciplinar que julga ser o ideal de educação. Os/as alunos/as que questionam ou não respondem positivamente a essas normativas são vistos como subversivos ou "casos perdidos". Sabemos que os dispositivos de poder não possuem apenas um lado negativo. Entretanto o que presenciamos no espaço escolar foi o uso desses dispositivos apenas para a manutenção do sistema econômico, sendo este o ideal predominante na escola contemporânea, pois são raros os momentos em que a escola atua em prol de uma atuação crítica dos sujeitos que dela fazem parte.

\section{Referências}

BRASIL. Lei n.13.005, de 25 de junho de 2014. Aprova o Plano Nacional de Educação - PNE e dá outras providências. Diário Oficial da União, Brasília, DF., 26 jun. 2014. Disponível em: <https://www.planalto.gov.br/ccivil_03/_ato20112014/2014/lei/113005.htm>. Acesso em: dez. 2017.

curricular. Brasília, DF, 2016. Disponível em: < http://basenacionalcomum.mec.gov.br/\#/site/inicio>. Acesso em: dez. 2017.

CONNELL, Raelwyn W. Como teorizar o patriarcado. Educação \& Realidade, Porto Alegre, v. 16, n. 2, p. 85-93, 1990.

Masculinidade Hegemônica: Repensando o Conceito. Estudos Feministas, v. 21, n. 1, 2013. ISSN 0104-026X. Disponível em: http://www.scielo.br/scielo.php?script=sci arttext\&pid=S0104-026X2013000100014. Acesso em: fev. 2017. 
FORQUIN, Jean-Claude. Escola e cultura: as bases sociais e epistemológicas do conhecimento escolar. Tradução: Guacira Lopes Louro. Porto Alegre: Artes Médicas, 1993.

FRANCO, Maria Amélia do Rosario Santoro. Prática pedagógica e docência: um olhar a partir da epistemologia do conceito. Rev. Bras. Estudos Pedagógicos. Brasília, v. 97, n. 247, set./dez. 2016. ISSN 0034-7183. Disponível em: http://www.scielo.br/scielo.php?pid=S217666812016000300534\&script=sci_abstract\&tlng=pt. Acesso em: fev. 2018.

GIROUX, Henry A. Os professores como intelectuais: rumo a uma pedagogia crítica da aprendizagem. Tradução de Daniel Bueno. Porto Alegre: Artes Médicas, 1997.

GRAMSCI, Antonio. Concepção dialética da história. Rio de Janeiro: Civilização Brasileira, 1978.

KONDER, Leandro. O futuro da filosofia da práxis: o pensamento de Marx no século XXI. 2 ed. Rio de Janeiro: Paz e Terra, 1992.

LOURO, Guacira Lopes. Uma leitura da história da educação sob a perspectiva de gênero. Projeto História, São Paulo, v. 11, 1994.

MARTINS, Aline Madalena. A formação continuada de professores/as sobre gênero e sexualidade: contribuições para uma nova prática pedagógica. Dissertação (Mestrado em Educação) - Programa de Pós graduação em Educação, Universidade do Sul de Santa Catarina. Tubarão, 153 p. 2019.

MATTOS, Amana; MAGALDI, Ana Maria Bandeira de Mello; COSTA, Carina Martins; SILVA, Conceição Firmina Seixas; PENNA, Fernando de Araújo; VELlOSO, Luciana; LEONARDI, Paula; ALBERTI, Verena. Educação e liberdade: apontamentos para um bom combate ao Projeto de Lei Escola sem Partido. In: FRIGOTTO, Gaudêncio (Org). Escola "sem" partido: esfinge que ameaça a educação e a sociedade brasileira. Rio de Janeiro: UERJ, LPP, 2017, p. 87-104.

MENDONÇA, Amanda André de; MOURA, Fernanda Pereira de. "Ideologia de gênero" e escola sem partido: a agenda privatizante moralizadora para a educação brasileira. Revista Interinstitucional Artes de Educar. Rio de Janeiro, v. 5, n. 2, ago. 2019. Disponível em: https://www.e-publicacoes.uerj.br/index.php/riae/article/view/44849/30394. Acesso em: 28 mar. 2021.

MIGUEL, Luis Felipe. Da "doutrinação marxista" à "ideologia de gênero" - Escola Sem Partido e as leis da mordaça no parlamento brasileiro. Revista Direito e Práxis. Universidade do Estado do Rio de Janeiro. v. 7, n. 15, 2016. Disponível em: Disponível em: http://www.redalyc.org/articulo.oa?id=350947688019. Acesso em: 10 ju. 2021.

MOURA, Fernanda Pereira de. "Escola Sem Partido": relações entre Estado, educação e religião e os impactos no ensino de história. 2016. 89 f. Dissertação - (Mestrado Profissional em Ensino de História) Instituto de História, Universidade Federal do Rio de Janeiro, Rio de Janeiro. 
NÓVOA, Antônio. Para uma formação de professores construída dentro da profissão. Revista Educacion. $\quad 2009 . \quad$ Dadrid: 201 em: http://www.revistaeducacion.educacion.es/re350/re350_09por.pdf. Acesso em: jun. 2017.

PIMENTA, Selma Garrido. Formação de professores: saberes da docência e identidade do professor. Revista da Faculdade de Educação, USP, v. 1. n. 1, p. 72-89, jul./dez. 1996.

PIMENTA, Selma Garrido; GHEDIN, Evandro. (Org.). Professor Reflexivo no Brasil: gênese e crítica de um conceito. São Paulo: Cortez, 2002.

STROMQUIST, Nelly. Qualidade de ensino e gênero nas políticas educacionais contemporâneas na América Latina. Educação e Pesquisa, São Paulo, v.33, n.1, p. 13-25, jan./abr. 2007. ISSN 1517-9702. Disponível em: http://www.scielo.br/scielo.php?pid=S151797022007000100002\&script=sci_abstract\&tlng=pt. Acesso em out. de 2017.

THOMPSON, Edward Paul. A miséria da teoria ou um planetário de erros: uma crítica ao pensamento de Althusser. Rio de Janeiro: Zahar, 1981.

VÁZQUEZ, Adolfo Sánchez. Filosofia da práxis. Tradução de Luiz Fernando Cardoso. 2. ed. Rio de Janeiro: Paz e Terra, 1997.

WOOD, Ellen Meiksins. Democracia contra o capitalismo: a renovação do materialismo histórico. São Paulo: Boitempo, 2007.

\footnotetext{
${ }^{\text {i }}$ Esse não é o foco do estudo, mas cabe ressaltar que as práticas binárias também estão presentes em todo tempoespaço da escola, sendo essa uma prática marcante das normativas disciplinares.

ii $\mathrm{O}$ fato de a Escola Pública brasileira ser laica é ignorado, bem como a possibilidade de haver entre o público presente adeptos de outras religiões, que não as cristãs.

iii Durante as $100 \mathrm{~h}$ de observação que fizemos em cada turma, só foram trabalhados conteúdos de português e matemática.
} 